\author{
Інна Червінська, \\ кандидат педагогічних наук, доцент кафедри \\ педагогіки початкової освіти, \\ ДВНЗ «Прикарпатський національний університет \\ імені Василя Стефаника» \\ (м. Івано-Франківськ, Україна) \\ Inna Chervinska, \\ PhD in Education, Associate Professor, \\ Department of Pedagogy of Primary Education, \\ Vasyl Stefanyk Precarpathian national university \\ (Ivano-Frankivsk, Ukraine) \\ chervinska.inna@gmail.com \\ ORCID ID 0000-0003-0745-1413
}

Удк 37.015.31

\title{
ПСИХОЛОГО-ПЕДАГОГІЧНИЙ АСПЕКТ ФОРМУВАННЯ СОЦІОКУЛЬТУРНОЇ ІДЕНТИЧНОСТІ УЧНІВ ГІРСЬКИХ ШКІЛ РЕГІОНУ УКРАЇНСЬКИХ КАРПАТ
}

Анотація. У статті проаналізовано теоретичні підходи до феномену соціокультурна ідентичність, визначено психолого-педагогічні засади формування соціокультурної ідентичності учнів гірських шкіл регіону Українських Карпат. 3 метою дослідження методологічних, концептуальних і методичних підходів, які розкривають різні варіанти характеристики поняття «соціокультурна ідентичність» у контексті міждисциплінарного дискурсу обґрунтовано природу ідентичності, зумовлену потребою зростаючої особистості у визнанні серед інших успішної самореалізації. Метою дослідження є опис регіональних особливостей процесу формування соціокультурної ідентичності учнів гірських шкіл у контексті сталого розвитку регіону Українських Карпат.

Наголошується, що конвергентність застосування методологічних підходів, принципів, методів, форм та ідей зумовлює інноваційні шляхи розв'язання проблеми формування соціокультурної ідентичності зростаючої особистості в освітньому процесі та в позакласній діяльності закладу загальної середньої освіти гірського регіону. Акцентується увага на процесі формування соціокультурної ідентичності особистості в сучасному суспільстві, яка є складною і водночас актуальною проблемою, яка уможливлює більш ґрунтовно зрозуміти специфіку взаємин людини й суспільства, людини й середовища та спрогнозувати можливі варіанти розвитку соціальних процесів, розробити теоретичне підґрунтя нових уявлень про соціокультурний розвиток особистості.

Ключові слова: ідентичність, соціокультурний простір, соціокультурна ідентичність, регіональні особливості, Карпатський регіон, освітній потенціал, освіта, гірська школа.

\section{PSYCHOLOGICAL AND PEDAGOGICAL ASPECT FORMATION OF SOCIO-CULTURAL IDENTITY OF PUPILS OF MOUNTAIN SCHOOLS REGION OF THE UKRAINIAN CARPATHIANS}

\begin{abstract}
The article analyzes the theoretical approaches to the phenomenon of socio-cultural identity, identifies the psychological and pedagogical principles of formation of socio-cultural identity of students of mountain schools in the Ukrainian Carpathians. In order to study methodological, conceptual and methodological approaches that reveal different options for characterizing the concept of sociocultural identity in the context of interdisciplinary discourse, the nature of identity due to the need of a growing individual to recognize, among others, successful self-realization. It is noted that on the basis of the analysis of the latest scientific researches it is possible to assert about rather intensive studying of a problem of identity from the point of view of its socioculturality, formation of sociocultural identity of the young person. The aim of the study is to describe the regional features of the process of forming the socio-cultural identity of mountain school students in the context of sustainable development of the Ukrainian Carpathians region. It is emphasized that the convergence of methodological approaches, principles, methods, forms and ideas determines innovative ways to solve the problem of forming the socio-cultural identity of a growing individual in the educational process and extracurricular activities of general secondary education in the mountain region. Emphasis is placed on the process of forming the socio-cultural identity of the individual in modern society, which is a complex and, at the same time, relevant problem that allows a more thorough understanding of the relationship between man and society, man and environment and predict possible options for social processes sociocultural development of personality. The study points out that the issue of studying the essence of socio-cultural identification includes descriptive characteristics of both the individual and the whole social group and serves as a methodological basis for better understanding and explaining the mechanisms of personality structure, individual group consciousness and typical in certain communities of lifestyles, norms and rules of conduct. It is actualized and proved that in modern conditions the formation of socio-cultural identity requires purposeful organizational and pedagogical, coordinating activities of teachers, parents and students.
\end{abstract}

Keywords: identity, socio-cultural space, socio-cultural identity, regional features, Carpathian region, educational potential, education, mountain school. 


\section{ВСТУП}

Постановка проблеми. У традиційному соціумі соціокультурну ідентичність зазвичай трактують як певну сутність та властивість індивіда, яка належить йому від народження та не може бути змінена. Сучасні теоретичні візії ідентичності позиціонують її як феномен, що «конструюється» індивідом, групою та суспільством упродовж певного часу та в певному просторі.

3 позицій конструктивістського підходу проблема дослідження акцентується на динамічних змінах у процесі формування соціокультурної ідентичності, які зумовлені глобалізацією, розвитком інформаційного суспільства та кризою національної ідентичності.

Актуальність теми дослідження визначається сучасним станом наукового знання про феномен ідентичності та ідентифікації особистості.

Аналіз наукових досліджень і публікацій. Ключові аспекти проблеми дослідження соціокультурних аспектів розвитку особистості були вивчені в працях Г. Шевченко, Т. Комарової, Т. Ісаєвої та інших науковців. Сучасні дослідники Г. Касьянова, Д. Колесов, С. Макеєв, Л. Нагорна, М. Степико, С. Оксамитна, О. Швачко розкривають авторські погляди на поняття «ідентичність». Щодо висвітлення проблем взаємодії та взаємовпливу освіти і культури, розкриття й реалізації її значного освітнього потенціалу, то для нашого дослідження певну цінність становлять праці: Л. Масол, О. Отич, О. Рудницької, В. Петрушенка, Б. Нєменського та ін. У цьому контексті варто відзначити дослідження С. Макеєва «Соціальні ідентифікації та ідентичності» (Макеєв С., 1996), М. Шульги «Етнічна самоідентифікація особистості» (Шульга М., 2012), монографію П. Гнатенка та В. Павленко «Ідентичність: філософський та психологічний аналіз» (Гнатенко П. \& Павленко В., 1999) та ін. Аналіз останніх наукових досліджень свідчить про досить інтенсивне вивчення проблеми ідентичності саме з точки зору її соціокультурності, тобто формування соціокультурної ідентичності молодої людини.

\section{МЕТА І ЗАВДАННЯ ДОСЛІДЖЕННЯ}

Метою дослідження $€$ опис регіональних особливостей процесу формування соціокультурної ідентичності учнів гірських шкіл у контексті сталого розвитку регіону Українських Карпат.

До провідних завдань дослідження відносимо: визначення шляхів підвищення ефективності педагогічної діяльності щодо формування соціокультурної ідентичності учнів освітніми закладами гірських регіонів; підвищення рівня соціокультурної грамотності, формування екологічної свідомості та критичного мислення жителів гірських територій; дослідження механізмів формування соціокультурної ідентичності на сучасному етапі розвитку системи освіти; розкриття регіональних особливостей процесу формування соціокультурної ідентичності школярів.

\section{МЕТОДИ ДОСЛІДЖЕННЯ}

Методологія дослідження включає загальнонаукові методи дослідження: порівняння й аналогія, аналіз і синтез, дедукція та індукція, методи абстракції, класифікації, систематизації. Широко використовувалися загальнофілософські, етнографічні та історичні методи під час аналізу наукових джерел. Застосування методів порівняння уможливило виявити найбільш істотні деталі, риси, подібності та відмінності між різними об'єктами, явищами та процесами на різних територіях певного регіону. Методи аналізу та синтезу застосовувалися під час вивчення структури та компонентів соціокультурної ідентичності молодої людини.

\section{РЕЗУЛЬТАТИ ДОСЛІДЖЕННЯ}

У вітчизняній психолого-педагогічній та філософській думці ідентичність стала об'єктом уваги науковців відносно недавно. Незважаючи на те, що саме поняття ідентичності має досить тривалу історію, теоретична розробка та ґрунтовні емпіричні дослідження проблеми ідентичності розпочалися ще в 50-70 роки XX століття. У цей період термін «ідентичність» набуває поширення у США завдяки працям основоположника теорії ідентичності Е. Еріксона, який розглядав ідентичність як процес, зосереджений на сутності людини і культури, до якої цей індивід належить. Відомий дослідник вказував на всеосяжний характер та змістовну широту сутності поняття «ідентичність» (Еріксон Е., 2000).

Термін «ідентичність» - (identitas) - тотожність, є похідним від займенника idem, eadem - «той самий», тобто «identitas», означає «те ж саме», «тотожність» (Голованов О., 2001). Ідентичність - це неоднозначна структура, що розвивається впродовж усього життя особистості, змінюється в прогресивному й регресивному напрямах, проходить через подолання нею життєвих криз та викликів. Ідентичність виступає як первинна й необхідна умова для розвитку особистості (Литвинчук О., 2011).

В українських наукових колах слово «ідентичність» з'являється у 60-х роках XIX ст. і здебільшого трактується як тотожність, що означає відповідність, збіг з ким- або чим-небудь. Зазвичай переклад слова «іdentity» трактується як впізнавання, або ж як ототожнення. Відповідно під ідентичністю розуміють певну тотожність чи ототожнення людини 3 нацією, класом, статтю, культурними надбаннями, географічним середовищем, соціальним устроєм певної спільноти.

Досліджуючи ідентичність, слід виходити з того, що це соціальний і культурний феномен, який виник через потребу людини належати до дуже специфічних великих соціальних груп - етносу та нації, долучатися до надбань національної культури й творити її. «Зважаючи на спосіб трактування природи цих груп соціальною психологією, вона розглядається як така, що пов'язана не лише з заданими параметрами, але і зі свідомим вибором особистості» (Кухарук О, 2015, с.103).

3 точки зору класичних філософських та психолого-педагогічних традицій, ідентичність - фундаментальна характеристика буття, яка передбачає зберігання тотожності самому собі і протистоїть "відмінності». Це одна з найважливіших характеристик особистості, що означає єдність, цілісність індивіда в часі і просторі (Заковоротна М., 1999). І якщо введення до наукового дискурсу дефініції «ідентичність» пов'язують з іменами Е. Еріксона та Е. Фромма, то безпосередньо у площині літератури це поняття вжив 1928 року З. Фрейд у праці «Масова психологія і аналіз людського Я» (1928), використавши термін «ідентифікація» (ототожнення), який характеризував первинний 
прояв емоційного зв'язку з іншим собою. Відомий психолог характеризував ідентифікацію як несвідомий процес наслідування; як найперший прояв емоційної прив'язаності дитини до матері, емоційне злиття з нею; спосіб захисту особистості від тиску інстинктів; ...через ототожнення дитиною себе з батьками чи іншим авторитетом та, відповідно, інтеріоризація їх моральних норм, цінностей, зразків поведінки (Фрейд З., 1991).

Зазвичай прийнято розрізняти етнічну ідентичність, класову ідентичність, культурну, расову соціокультурну та інші її види.

У сучасному науковому дискурсі терміни «ідентичність» та «ідентифікація» набувають особливої популярності, «оскільки суспільство рухається в напрямі прискореного розвитку усіх сфер життєдіяльності молодої людини. Однак такий різкий вектор змін не виключає, а навпаки - посилює вагомість розгляду проблеми соціокультурної ідентичності особистості та нації на загал» (Литвинчук О., 2011, с.197).

Поняття «соціокультурна ідентичність» $€$ складною категорією, засадничими основами якої виступають історична правда, історична пам'ять, національна гідність, національна самосвідомість, національні цінності та ідеали.

Теоретико-прикладні засади сучасного уявлення та трактування соціокультурної ідентичності особистості становить загальна концепція соціокультурної динаміки, творцем якої є П. Сорокін (1889-1968). Соціальну стратифікацію або ж певне розшарування суспільства, на думку П. Сорокіна, становить політична, економічна та професійна стратифікації. Учений у відомій книзі «Соціальна і культурна динаміка» (2016) описує процес розвитку культур народів і розробляє теорію цінностей, що є висхідним для нашого дослідження. Дефініція «цінність» стає в центрі його наукових доробок, оскільки за її допомогою автор розкриває сутність поведінки особи і соціальних груп, принципи їх взаємодії у всіх різних напрямах (Сорокін П., 2016, с. 84).

Суголосні до попереднього визначення й трактування науковців І. Беха та К. Журби, висвітлені ними у «Концепції з формування у підлітків національно-культурної ідентичності у загальноосвітніх навчальних закладах» (2018). Так, зокрема, зазначається, що «ідентичність - внутрішній, суб'єктивний стан особистості, у якому виражається усвідомлення нею себе як своєрідної стійкості особистості, як самототожності, переживання постійно наявного Я, його збереження. Тому переживання є досить важливою характеристикою особи стосовно її ідентичності. Оскільки ідентичність пов'язується з структурною цілісністю особистості, то їі доцільно співвідносити з ідентифікацією, яку на сьогодні визначають «як механізм і процес, що забезпечують формування ідентичності» (Бех І. \& Журба К., 2019, с.7).

Відомий дослідник проблеми ідентичності - філософ і педагог - М. Козловець визначив основні чинники, що впливають на формування ідентичності. До них дослідник відносить: історичну територію, яка визначена згідно підпорядкуванню держави міжнародному праву - a state under international law);спільність мови і культури; єдиний економічний простір; релігію і спільну міфологію; історичну пам'ять; єдині закони і обов'язки для всіх членів спільноти; святість і всесвітню значущість (Козловець М., 2009, с.71).

Вивчення психолого-педагогічних аспектів формування соціокультурної ідентичності учнів гірських шкіл у часопросторі освіти є складним, трудомістким «і відносно новим процесом у науковому пізнанні життєвго світу людини та способів її взаємодії із культурними надбаннями, яке виробило впродовж віків людство (Посохова Я. 2015, с.217).

Соціокультурну ідентичність можна представити як процес ототожнення особистості з певними культурними ідеалами, які сформувалися впродовж певного історичного періоду в національній культурі, традиціях та побуті країни на основі морально-духовних цінностей, історичних пам'яток та колективної пам'яті, що зберігаються і ретранслюються прийдешнім поколінням як національне надбання. Формування соціокультурної ідентичності зростаючої особистості ґрунтується на національному світогляді, національній культурі, мові, національних ідеях історії та традиціях, на надбаннях національної пам'яті в поєднанні з інноваційними здобутками сьогодення. Тому прийоми і методи цього неоднозначного процесу базуються на засадах народної педагогіки, зважаючи на їі тісний зв'язок з родинними цінностями, а отже, і з наближеністю до емоційно-почуттєвої сфери дитини, що здатна істотно сприяти стійкому засвоєнню структур соціокультурної ідентичності учнів гірських шкіл.

у формуванні соціокультурної ідентичності сучасної молодої людини, яка проживає в умовах гірського середовища, суттєвим є такий чинник, як яскраво виражена тенденція до соціалізації. Оскільки вона зростає і розвивається в дещо обмеженому просторі за умов високогір'я й переживає внутрішні психологічні та фізіологічні зміни, то передовсім прагне розширити або ж укріпити свої соціальні ролі.

Молоді люди, інколи навіть досить прискіпливо, проявляють занепокоєння тим, як вони виглядають, як їх сприймають інші у порівнянні з тим, що вони самі думають про себе. Для них важливо, як поєднати ті соціальні ролі, норми й звички поведінки, які культивувалися в них дещо раніше, із урахуванням запропонованих ідеалів та прототипів для наслідування.

Таким чином, почуття причетності до власної соціокультурної ідентичності формує у зростаючої особистості впевненість у тому, що її здатність зберігати внутрішню тотожність і цілісність узгоджується з оцінкою її тотожності й цілісності, які дають інші. За вказаних обставин вона повинна добре знати й свою історію, традиції, культуру, позитивно сприймати героїчні приклади славного минулого, якими так багата українська культурно-історична спадщина. Це дасть можливість школярам-випускникам зрозуміти, що вони належать до сильного, самобутнього, талановитого, мужнього й працьовитого народу. Адже в такий спосіб отримуються не лише знання про минуле, а й проходить виховання національно-свідомої особистості.

Активне застосування у виховному процесі сучасної школи таких народно-педагогічних засобів, як рідна мова, усна творчість, народна музика, народні промисли та ремесла, атмосфера рідної домівки тощо, сприяє підвищенню ефективності формування соціокультурної ідентичності школярів. Саме народні традиції та календарно-побутова обрядовість, якої дотримуються горяни, виступає тим своєрідним полем поєднання і зіставлення індивідуальної та групової ідентичності, оскільки людина через різні обряди, ритуали, танці та дії виокремлює ті компоненти 
обрядовості, які їй найближчі, і цим формує певне особисте тло, що простежується у сприйнятті, але підкоряється і слідує загальній традиції.

Оскільки формуванню соціокультурної ідентичності учнів гірських шкіл регіону Українських Карпат приділяють увагу багато державних інституцій, то серед важливих компонентів цього неоднозначного процесу доцільно також виокремити роботу закладів освіти та організацію соціокультурної діяльності закладів позашкільної освіти.

у більшості досліджень феномена соціокультурної ідентичності відзначається, що різні соціокультурні умови, залежно від середовища, діяльності засобів масової інформації та розвитку, субкультури, різним чином сприяють або ж перешкоджають розширенню простору життєдіяльності людини.

Багато дослідників (А. Качкін, Л. Махлін, Л. Лембрик-Орбан, В. Шкуратов та ін.) вказують на певні відмінності в мисленні, поведінці, ціннісних орієнтаціях мешканців мегаполісу і мешканців віддаленого високогірного села чи гірського містечка. Адже, народившись та зростаючи у певному географічному середовищі, перебуваючи під впливом соціокультурного простору, із урахування етнокультурної специфіки регіону, людина засвоює усталені в ньому регулятиви (правила або вимоги, з яким люди вибудовують свою поведінку й визначають подальші основи життєдіяльності), унаслідок чого «ії дії виявляються значною мірою зумовлені ними. А особистість реалізує у своїх вчинках і на своєму життєвому шляху накладені культурні нашарування та програми поведінки, часто навіть не усвідомлені нею» (Леонтьев Д, 2009, с.6).

Готовність учнів гірських шкіл сприймати різноманітні прийоми й засоби народної педагогіки підтверджують ії високу ефективність у процесі формування соціокультурної ідентичності. Зважаючи на те, що територіально населення регіону Українських Карпат включає в себе представників різних етнічних груп, педагогам, батькам та представникам громадськості варто звертати увагу під час освітньої діяльності на розв'язання проблем толерантності в царині полікультурних взаємин, унеможливлюючи таким чином причини виникнення різноманітних конфліктів на етнічному та полікультурному ґрунті.

Отже, процес формування соціокультурної ідентичності охоплює увесь комплекс взаємин у взаємодії особистості із суспільством, включаючи психолого-педагогічні, соціально-культурні, етнічні, економічні та політичні складники.

У зазначеному контексті результати вивчення проблеми соціокультурної ідентичності зростаючої особистості як підгрунтя «стійкості життєвого світу людини» (Логінова І., Живаєва Ю., 2013) зможуть слугувати добрим підгрунтям для регіональних програм соціально-психологічного супроводу для молодих людей, які переселяються з малих міст гірських регіонів країни в мегаполіси та рівнинні міста та певним дороговказом для випускників гірських освітніх закладів, які зазнають певних труднощів у професійному самовизначенні, тощо.

Така багатоваріантність палітри прояву соціальних ситуацій впливає на процес становлення ідентичності молодих людей, мешканців гірських районів. Оскільки формування ідентичності зростаючої особистості на місцевому чи регіональному рівні сприяє покращенню якості та успішності модернізації сучасного суспільства, збереження його єдності і соціальної стабільності закладає основи для її досягнення як на регіональному, так і на загальнодержавному рівні.

Бурхливі глобалізаційні виклики останніх десятиліть зумовили зміну сформованих суспільних стереотипів та докорінну перебудову освітнього, культурного, соціально-економічного життя регіону Українських Карпат, викликали кардинальні перетворення і в соціокультурній та освітній сфері. Ці процеси в комплексі сприяли широкомасштабному розвитку міграційних процесів, основу яких становили молоді люди, вихідці з віддалених від центру, депресивних гірських районів. На території регіону переважає гірський тип поселення, за якого простежуються мала густота населення, велика протяжність територій, розкидане розміщення населених пунктів, певна віддаленість від сучасних освітньо-культурних центрів та великих міст. I тому віддалене гірське село чи містечко, на відміну від мегаполісу, який $є$ показником економічного розвитку та прикладом урбанізації, характеризується за таких обставин як індикатор соціального і морального здоров'я населення й виступає разом з громадою хранителем культурних надбань, історичної спадщини свого краю та його мешканців, носієм національної автентичності. При цьому в умовах високогірного села чи малого містечка постає питання формування соціокультурної ідентичності школярів та молоді, яка становить основу для реалізації програм сталого розвитку регіону та суспільства назагал.

Для регіону Українських Карпат питання соціокультурної ідентичності молодих людей детермінується поліетнічністю та полікультурністю населення, що проживає на цій території. За даними Всеукраїнського перепису населення, на території України проживають представники понад 130 національностей та народностей і кожен із цих представників вважає той чи інший район своєю малою Батьківщиною. Тема соціокультурної ідентичності набирає особливої значущості саме в період формування нових стратегій сталого розвитку регіону, відповідно до ухвалених урядових програм та концепцій. За цих умов виникають суперечності між світовими проблемами глобалізації та можливостями розвитку молодої людини в умовах складного за життєвими показниками гірського регіону, яке реалізується на мікрорівні її трансформацій.

\section{ВИСНОВКИ ТА ПЕРСПЕКТИВИ ПОДАЛЬШИХ ДОСЛІДЖЕНЬ}

Отже, процес формування соціокультурної ідентичності охоплює увесь комплекс взаємин у взаємодії особистості із суспільством, включаючи психолого-педагогічні, соціально-культурні, етнічні, економічні та політичні складники.

Соціокультурна ідентичність та символи, що їі характеризують, визначають такі норми людської поведінки, які певним чином поєднуються з життєдіяльністю соціальної групи та з індивідами, які до неї входять, або суспільством загалом.

Перспективи подальших наукових розвідок пов'язуємо з проблематикою змістового наповнення та аналізу форм освітньої діяльності закладів загальної середньої освіти щодо формування соціокультурної ідентичності учнів. 


\section{СПИСОК ВИКОРИСТАНИХ ДЖЕРЕЛ}

Асмолов, А. Г. (2010). Стратегия социокультурной модернизации образования: на пути к преодолению кризиса идентичности и построению гражданского общества. Психолого-педагогический поиск, 14. 21-39.

Краткий словарь по социологии (2001) / Сост. О. С. Голованов. Кыштым : Кыштымский филиал ЮУрГУ.

Ганаба, С. (2019). Національно-культурна ідентичність особистості як умова консолідації суспільства. Формування в учнів основної школи національно-культурної ідентичності в контексті сучасних полікультурних впливів: посібник. / за ред. І.Д. Бех, О.М. Докукіна \& С.Д. Федоренко \& К.О. Журба. Київ: ІПВ.

Гнатенко, П. І. (1999). Ідентичність: філософський та психологічний аналіз / П. І. Гнатенко, В. М. Павленко. Київ : Apt-Прес.

Данилюк, І. В. \& Гресько, В.В.(2017). Психологічні особливості гармонізації етнічної самосвідомості українців. Проблеми політичної психології, 5 (19). 122-133.

Заковоротная, М. В. (1999). Идентичность человека. Социально-философские аспекты. Ростов н/Д.: Изд-во Северо-Кавказского науч. центра.

Кальной, И.И. (2004). Проблема идентичности в условиях трансформации современного украинского общества. Ученые записки ТНУ. Серия: Философия. Т. 17 (56), 2. 110-118.

Козловець, М. А. (2015). Феномен національної ідентичності: виклики глобалізації: монографія. Житомир: ЖДУ ім. І. Франка.

Кухарук, О. Ю. Теоретичні засади емпіричного дослідження етнонаціональної ідентичності. Психологічні науки: проблеми і здобутки, 7. $98-114$

Литвинчук, О. (2011). Соціальна та особистісна ідентичність: соціально-філософський аналіз Наукові записки Житомирського державного технологічного університету. Серія Філософія, 8. 195-202.

Логинова, И. О. \& Живаева, Ю. В. (2015). Особенности социокультурной идентичности студентов малого города и мегаполиса. Вестник КемГУ, 3 (63).

Леонтьев, Д. А. (2009). Лабиринт идентичностей: не человек для идентичности, а идентичность для человека. Философские науки, 10. $5-10$

Малінін, В. В. (2013). Соціокультурна ідентичність як чинник підвищення ефективності політичного управління. Актуальні проблеми політики, 48. 258-264.

Нагорна, Л.П. (2011). Соціокультурна ідентичність: пастки ціннісних розмежувань: монографія. Київ: ІПіЕНД ім. І.Ф.Кураса НАН України.

Посохова Я.С. (2015). Проблема ідентичності та визначення психологічних основ її вивчення. Право і безпека, 2 (57). $217-221$.

Сорокин, П.А. (2017). Социальная и культурная динамика / Пер. с англ. и коммент. В.В. Сапова. Москва: Академический проект.

Социологический энциклопедический словарь (1998). / [ред. Г. В. Осипов]. Москва: ИНФРА.

Філіпчук Г. (2016). Національна ідентичність: культурно-освітній вимір: монографія. Чернівці: Друк Арт.

Бех, І.Д. (2019). Формування в учнів основної школи національно-культурної ідентичності в контексті сучасних полікультурних впливів: посібник / [І.Д. Бех, О.М. Докукіна \&С.Д. Федоренко \& І.М. Шкільна \& К.О. Журба]. Київ: ІПВ.

Фрейд, 3. (1991). Введение в психоанализ : лекции. Москва: Наука.

Chervinska, I., \& Chervinskyi, A. (2020). Socio-cultural educational environment of the Ukrainian Carpathian region as a subject of interdisciplinary discourse. Human Studies. Series of Pedagogy, 10/42, 101-112. doi: https://doi.org/10.24919/2413-2039.10/42.198817

\section{REFERENCES}

Asmolov, AG (2010). Strategy of socio-cultural modernization of education: on the way to overcoming the identity crisis and building civil society. Psychological and pedagogical search, 14. 21-39.

Brief dictionary on sociology (2001) / Sost. O.S. Golovanov. Kyshtym: Kyshtym branch of SUSU

Ganaba, S. (2019). National and cultural identity of the individual as a condition for the consolidation of society. Formation of national-cultural identity in primary school students in the context of modern multicultural influences: a guide. / for ed. ID. Beh, O.M. Dokukina \& S.D. Fedorenko \& KO Sorrow. Kyiv: IPV.

Gnatenko, P. I. (1999). Identity: philosophical and psychological analysis / PI Gnatenko, VM Pavlenko. Kyiv: Apt-Press.

Danyliuk, IV \& Gresko, VV (2017). Psychological features of harmonization of ethnic self-consciousness of Ukrainians. Problems of political psychology, 5 (19). 122-133.

Zakovorotnaya, MV (1999). Human identity. Socio-philosophical aspects. Rostov n / D .: North Caucasus Publishing House. center.

Kalnoy II (2004). The problem of identity in the conditions of transformation of modern Ukrainian society. Scientific notes of TNU. Series: Philosophy. T. 17 (56), 2. 110-118.

Kozlovets, MA (2015). The phenomenon of national identity: the challenges of globalization: a monograph. Zhytomyr: ZhSU named after I. Franko. Kuharuk, O. Yu. Theoretical bases of empirical research of ethno-national identity. Psychological Sciences: Problems and Achievements, 7. 98-114.

Litvinchuk, O. (2011). Social and personal identity: socio-philosophical analysis Scientific notes of Zhytomyr State Technological University. Philosophy Series, 8. 195-202.

Loginova, IO \& Zhivaeva, Yu. V. (2015). Features of socio-cultural identity of students of a small town and a metropolis. Bulletin of KemSU, 3 (63).

Leontiev, DA (2009). The labyrinth of identities: not man for identity, but identity for man. Philosophical Sciences, 10. 5-10.

Malinin, VV (2013). Socio-cultural identity as a factor in improving the effectiveness of political governance. Current policy issues, 48. 258-264.

Nagorna, L.P. (2011). Sociocultural identity: traps of value distinctions. Kyiv: IPiEND named after IF Kuras NAS of Ukraine.

Posokhova Ya.S. (2015). The problem of identity and determining the psychological basis of its study. Law and Security, 2 (57). $217-221$.

Sorokin, P.A. (2017). Social and cultural dynamics / Per. with English and comment. VV Sapova. Moscow: Academic project.

Sociological Encyclopedic Dictionary (1998). / [ed. GV Osipov]. Moscow: INFRA.

Filipchuk G. (2016). National identity: cultural and educational dimension: monograph. Chernivtsi: Print Art.

Bech, I.D. (2019). Formation in students of the primary school of national-cultural identity in the context of modern multicultural influences: a manual / [I.D. Beh, O.M. Dokukina \& S.D. Fedorenko \& IM School \& K.O. Sorrow]. Kyiv: IPV.

Freud, Z. (1991). Introduction to psychoanalysis: lectures. Moscow: Science.

Chervinska, I., \& Chervinskyi, A. (2020). Socio-cultural educational environment of the Ukrainian Carpathian region as a subject of interdisciplinary discourse. Human Studies. Series of Pedagogy, 10/42, 101-112. doi: https://doi.org/10.24919/2413-2039.10/42.198817 